\title{
Modulation activity of heat-treated and untreated lactoferrin on the TLR-4 pathway in anoxia cell model and cerebral ischemia reperfusion mouse model
}

\author{
Huai-Gu Yang, ${ }^{1,2,3,4 *}$ Hui-Ying Li, ${ }^{1,2,3,4 *}$ Peng Li, ${ }^{1,2,3,4}$ Xiao-Yu Bao, ${ }^{1,2,3,4}$ Guo-Xin Huang, ${ }^{1,2,3,4}$ Lei Xing, ${ }^{1,2,3,4}$ \\ Nan Zheng,,$^{1,2,3,4} \dagger$ (i) and Jia-Qi Wang ${ }^{1,2,3,4}$ † (i) \\ ${ }^{1}$ State Key Laboratory of Animal Nutrition, Institute of Animal Sciences, Chinese Academy of Agricultural Sciences, Beijing 100193, P. R. China \\ ${ }^{2}$ Key Laboratory of Quality and Safety Control for Milk and Dairy Products of Ministry of Agriculture and Rural Affairs, Institute of Animal Sciences, \\ Chinese Academy of Agricultural Sciences, Beijing 100193, P. R. China \\ ${ }^{3}$ Laboratory of Quality and Safety Risk Assessment for Dairy Products of Ministry of Agriculture and Rural Affairs, Institute of Animal Sciences, \\ Chinese Academy of Agricultural Sciences, Beijing 100193, P. R. China \\ ${ }^{4}$ Institute of Animal Sciences, Chinese Academy of Agricultural Sciences, Beijing 100193, P. R. China
}

\begin{abstract}
This study aimed to investigate the modulation activity of heated and nonheated lactoferrins in an inflammatory pathway in anoxia and reoxygenation cell and cerebral ischemic reperfusion mouse models. Rat pheochromocytoma 12 (PC-12) cells were subjected to oxygen and glucose deprivation in vitro to construct an anoxia and reoxygenation cell model, and Institute for Cancer Research (ICR) mice were given carotid artery "ligation-relaxation" in vivo to construct a cerebral ischemic reperfusion mouse model. The protein levels of toll-like receptor 4 (TLR-4) and downstream inflammatory proteins including nuclear factor- $\kappa \mathrm{B}$ $(\mathrm{NF}-\kappa \mathrm{B})$, tumor necrosis factor- $\alpha$ (TNF- $\alpha)$, and IL-1 $\beta$ were detected. Meanwhile, metabonomic detection of overall metabolites of PC-12 cells was performed to screen out the specific changed metabolite affected by lactoferrin at the condition of anoxia and reoxygenation. The results showed that lactoferrin could inhibit the TLR-4-related pathway triggered by anoxia and reoxygenation and ischemic reperfusion. A total of 41 significantly changed metabolites were identified by metabonomic analysis, and glutathione was seen as a metabolite of interest in suppressing TLR-4-related pathway in anoxia and reoxygenation cell models. However, heated lactoferrin lost the ability of attenuating the TLR-4-related pathway. The loss of modulation activity of heated lactoferrin might be due to its protein aggregation, which was evidenced by larger average
\end{abstract}

Received May 22, 2019.

Accepted October 7, 2019.

*These authors contributed equally to this work.

†Corresponding authors: zhengnan_1980@126.com and jiaqiwang@ vip.163.com particle diameter than the unheated lactoferrin. This study is the first to investigate the effect of heat treatment on the modulation activity of lactoferrin in the TLR-4-related pathway in anoxia and reoxygenation cell and cerebral ischemic reperfusion mouse models, and indicate that lactoferrin may serve as a dietary intervention for cerebral ischemia.

Key words: heat treatment, lactoferrin, anoxia and reoxygenation, cerebral ischemic reperfusion

\section{INTRODUCTION}

Stroke, also known as apoplexy, is always accompanied by ischemia or hemorrhagic injury to brain tissue, which carries a high mortality and disability rate (Cao et al., 2007; Liu et al., 2017). Stroke can be divided into 2 types, hemorrhagic stroke commonly with subarachnoid hemorrhage, and ischemic reperfusion $(\mathbf{I} / \mathbf{R})$ with cerebral infarction or thrombosis; the morbidity rate of the latter is higher than $85 \%$ (Cao et al., 2007; Liu et al., 2017; Lu and Wang, 2017). In recent years, the mortality of stroke has been increasing with age, thus development of effective preventive drugs or dietary products deserves more investigation.

Accumulating evidence shows that cerebral ischemic reperfusion is always accompanied by substantial inflammatory reactions, which are initiated by the activation of chemokines, proinflammatory factors, adhesion molecules, and so on (Nagahiro et al., 1998; Nilupul Perera et al., 2006; Li et al., 2012). As a classical sensor and receptor to microorganisms and lipopolysaccharides, toll-like receptor 4 (TLR-4) is widely studied in triggering inflammatory response, by connecting with the downstream adapter molecule myeloid differentiation protein 88 (MyD88) and ensuing nuclear factor$\kappa \mathrm{B}$ protein $(\mathbf{N F}-\boldsymbol{\kappa} \mathbf{B})$, and then induced expression of inflammatory factors, such as tumor necrosis factor- $\alpha$ (TNF- $\boldsymbol{\alpha}$ ) and IL-1 $\beta$ (Akira and Takeda, 2004; Liu et 
al., 2014). Moreover, TLR-4 played an important part in regulating inflammatory responses of both microglia and neurons during cerebral ischemic reperfusion (Tang et al., 2008; Napoli and Neumann, 2009; Teeling and Perry, 2009; Yao et al., 2013).

A cohort study of 21 countries in 5 continents lasting for $9 \mathrm{yr}$ demonstrated that long-term consumption of dairy products could decrease the mortality or major cardiovascular disease incidents, including stroke (Dehghan et al., 2018). It assumed that a range of potential compounds in dairy foods might improve health (Dehghan et al., 2018). Among those potential compounds, lactoferrin ( $\mathbf{L F}, 80 \mathrm{kDa})$ is one of the most famous lactoproteins as it exerts multiple bioactivities of antiinflammation, anti-oxidation, anti-virus, anti-tumor, and so on (Chung et al., 2012; Donovan, 2016; Legrand, 2016; Okubo et al., 2016; Redwan et al., 2016; Sun et al., 2016; Li et al., 2019).

Furthermore, several studies have investigated and demonstrated the protective activity of LF in ischemia injury. Ikeda et al. (2013) found that bovine milk-derived lactoferrin promoted vascular endothelial cell function and thereby contributed to the revascularization in response to ischemic injury. Zhang et al. (2012) found that LF could serve as a potent supplement in protecting the gut from intestinal I/R-induced injury through its anti-oxidative, anti-inflammatory, and anti-apoptotic activities. van de Looij et al. (2014) demonstrated that LF given through lactation to rat pups with cerebral hypoxia-ischemia injury showed neuroprotective effects on brain metabolism, and recovery of the cerebral gray and white matter revealed by high-field multimodal magnetic resonance imaging. As brain injury resulting from hypoxia-ischemia has a high incidence in premature infants often accompanied by ensuing neurodevelopmental disabilities, LF might have potential application in protecting infants from neuronal damage.

The TLR-4 mediates inflammatory reaction during cerebral ischemic reperfusion. It has been found that LF could suppress the TLR-4 expression stimulated by lipopolysaccharide or its agonist (Ando et al., 2010; Puddu et al., 2011; Zhan et al., 2014). Whether or not LF could modulate TLR-4-related pathway caused by anoxia and reoxygenation and ischemic reperfusion is not clear. In addition, as a heat-sensitive and unstable glycoprotein, LF was easily inactivated when heated at neutral pH (Rüegg et al., 1977; Abe et al., 1991). Our recent study showed that heating at 70 or $100^{\circ} \mathrm{C}$ markedly decreased the anti-tumor effect of LF in the HT29 colorectal tumor model (Li et al., 2019). However, further studies are needed on the influence of heat treatment of LF on its modulation activity of the TLR- 4-related pathway caused by anoxia and reoxygenation and ischemic reperfusion.

In this study, rat pheochromocytoma 12 (PC-12) cells were subjected to oxygen and glucose deprivation to construct an anoxia and reoxygenation cell model, and mice carotid arteries were ligated to construct a cerebral ischemic reperfusion mouse model. Western blot was performed to compare the modulation ability of LF without/with heat treatments on TLR-4-related

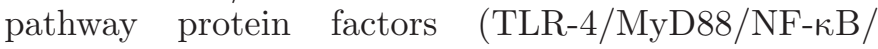
TNF- $\alpha /$ IL-1 $\beta$ ) in oxygen and glucose deprivation (OGD) PC-12 cells and I/R mouse brain tissue. Liquid chromatography-MS was also used to analyze changed metabolites, especially antioxidant metabolites in PC12 cells.

\section{MATERIALS AND METHODS}

\section{Chemicals}

The PC-12 cell line was purchased from the Chinese Academy of Science (Shanghai, China), and RPMI1640 medium, glucose-free RPMI-1640 medium, fetal bovine serum, and penicillin-streptomycin solution were purchased from Gibco (Grand Island, NY). Lactoferrin (partially iron saturated) at a purity greater than $90 \%$ and methylthiazoltetrazolium (MTT) were purchased from Sigma (San Francisco, CA). Antibodies to TLR-4, MyD88, NF- $\kappa$ B, TNF- $\alpha$, IL-1 $\beta$, and $\beta$-actin, as well as the related secondary antibodies were purchased from Santa Cruz (San Francisco, CA). Reagents for the Western blotting assay were purchased from Solarbio (Beijing, China). The enhanced chemiluminescence reagent was purchased from Thermo Fisher Scientific (Waltham, MA).

\section{Animal Feeding}

The Institute for Cancer Research (ICR) male mice (18-22 g) were purchased from Vital River Laboratory Animal Technology Co., Ltd. (Beijing, China; license number SCXK 2012-0001). The mice were kept in cages at a constant temperature of $25^{\circ} \mathrm{C}$ and relative humidity of $50 \%$, and 5 mice were kept per cage. The mice were acclimated for $7 \mathrm{~d}$ before the formal experiment. The protocol in the present study was approved by the Committee on the Ethics of Animal Experiments of the Chinese Academy of Agriculture Sciences (Beijing, China; permission number: IAS20181020), conforming to internationally accepted principles in the care and use of experimental animals (NRC, 2011). All surgeries were performed under sodium pentobarbital anesthesia, and all efforts were made to minimize suffering. 


\section{Cell Viability Assay}

The MTT assay was conducted to test cell viability at different concentrations of LF. Briefly, LF powder was dissolved in PBS to make a stock solution $(10,000$ $\mathrm{mg} / \mathrm{L}$ ), and RPMI-1640 medium (fetal bovine serum free) was used to dilute LF stock solution to different working solutions $(0-5,000 \mathrm{mg} / \mathrm{L})$. The PC-12 cells grew until confluence of $70 \%$ in a 96 -well plate, and the medium was replaced with different LF working solutions, and cells were continuously incubated for 48 h. Then, MTT solution was added (final concentration in wells, $0.5 \mathrm{mg} / \mathrm{mL}$ ) into each well, and the supernatant was aspirated $4 \mathrm{~h}$ later. Dimethyl sulfoxide (150 $\mu \mathrm{L} /$ well) was added, and absorbance at $490 \mathrm{~nm}$ was recorded.

\section{Heated LF Solution Preparation}

Lactoferrin powder was dissolved in PBS to make a final concentration of $10 \mathrm{mg} / \mathrm{mL}$. The tubes containing LF solutions were immersed into an electro-thermostatic water bath (Kuansons, Shanghai, China) with 3 different temperatures $\left(50,70\right.$, and $\left.100^{\circ} \mathrm{C}\right)$ for $3 \mathrm{~min}$. One $\mathrm{mg} / \mathrm{mL}$ LF (in RPMI-1640 medium) for the anoxia and reoxygenation cell model, and an oral dosage of 100 $\mathrm{mg}$ of $\mathrm{LF} / \mathrm{kg}$ of $\mathrm{BW}$ for the cerebral ischemic reperfusion mouse model, were selected, respectively, based on previous studies (Togawa et al., 2002; Hayashida et al., 2004; Dial et al., 2005; Li et al., 2019).

\section{Anoxia and Reoxygenation Cell Model Construction}

Previous studies were followed in constructing anoxia and reoxygenation cell model with minor modifications (Xu et al., 2007; Zhu et al., 2010; Martin-de-Saavedra et al., 2011; Andreev et al., 2015). Briefly, PC-12 cells were incubated with RPMI-1640 glucose-free medium in an special incubator with $95 \% \mathrm{~N}_{2}$ and $5 \% \mathrm{CO}_{2}$ at $37^{\circ} \mathrm{C}$ for $2 \mathrm{~h}$, and then, this medium was replaced with the normal RPMI-1640 medium (with glucose), and cell plates were moved to a $5 \% \mathrm{CO}_{2}$ incubator for another $2 \mathrm{~h}$ of incubation. In LF treatment groups, LF working solutions were added into the cell wells $4 \mathrm{~h}$ before replacement with RPMI-1640 glucose-free medium, and the subsequent procedures were the same with the OGD group.

\section{Cerebral Ischemic Reperfusion Model Construction}

Forty healthy male ICR mice (18-22 g) were divided into 8 groups: control group, I/R group, LF group, LF $\left(70^{\circ} \mathrm{C}\right)$ group, $\mathrm{LF}\left(100^{\circ} \mathrm{C}\right)$ group, I/R $+\mathrm{LF}$ group, I/R $+\mathrm{LF}\left(70^{\circ} \mathrm{C}\right)$ group, and $\mathrm{I} / \mathrm{R}+\mathrm{LF}\left(100^{\circ} \mathrm{C}\right)$ group. The mice in the $\mathrm{I} / \mathrm{R}$ groups were subjected to an operation ligating their carotid arteries for $15 \mathrm{~min}$, and then their carotid arteries were relaxed for $5 \mathrm{~min}$; the ligationrelax course was repeated 3 times. Mice in the LF treatment groups were gavaged with LF at a dosage of 100 $\mathrm{mg} / \mathrm{kg}$ of BW $6 \mathrm{~h}$ before I/R. The mice were killed $4 \mathrm{~h}$ after the ligation-relax operation, and the brain tissue was isolated.

\section{Detection of TLR-4/MyD88/NF-KB/TNF- $\alpha / I L-1 \beta$ Pathway Proteins by Western Blotting}

Cells in anoxia and reoxygenation cell model assay were lysed with lysis buffer (Solarbio) containing protease inhibitors, and lysates were then centrifuged at $7,500 \times g$ and $4^{\circ} \mathrm{C}$ for $5 \mathrm{~min}$. And the mouse brain tissue was frozen in liquid $\mathrm{N}_{2}$ and homogenized rapidly, and then treated with lysis buffer and centrifuged at $10,000 \times g\left(4^{\circ} \mathrm{C}, 10 \mathrm{~min}\right)$. Following heat treatment at $90^{\circ} \mathrm{C}$ for $10 \mathrm{~min}$, the protein samples were subjected to $12 \%$ SDS-PAGE, and the protein samples were then transferred onto a nitrocellulose membrane by dry Trans-Blot machines (Invitrogen, Carlsbad, CA). The membrane was blocked with $5 \%$ skim milk powder in TBST buffer for $1.5 \mathrm{~h}$ at room temperature. The TLR4, MyD88, NF- $\kappa B$, TNF- $\alpha$, IL- $1 \beta$, and $\beta$-actin proteins were then probed with primary antibodies for $2 \mathrm{~h}$ at room temperature. $\beta$-Actin was used as the internal reference to calibrate equal loading. After 3 washes with TBST buffer $(6 \mathrm{~min} \times 3)$, the membrane was incubated with secondary antibodies at room temperature for $1 \mathrm{~h}$ and then washed $(10 \mathrm{~min} \times 4)$. The protein bands in membranes were finally captured with enhanced chemiluminescence reagent and analyzed by Image J software (National Institutes of Health, Bethesda, MD).

\section{Metabonomic Analysis of PC-12 Cells Subjected to OGD With or Without Lactoferrin Treatment}

The PC-12 cells subjected to OGD with or without LF treatment were harvested. Then the cells were lysed by the lysis solution $(70 \%$ methanol $+0.1 \%$ formic acid). After vortex for $10 \mathrm{~s}$ and ultrasonication for 20 $\mathrm{min}$, the lysate was centrifuged at $10,000 \times g$ for $10 \mathrm{~min}$ at $4^{\circ} \mathrm{C}$, and the supernatant was collected. Metabolites in PC-12 cells were separated and identified by liquid chromatography coupled with MS. Chromatographic separation was performed on an ACQUITY UPLC system I class (Waters Corporation, Milford, MA). The column was a BEH C18 column $(100 \mathrm{~mm} \times 2.1 \mathrm{~mm}$ i.d., $1.7 \mu \mathrm{m}$, Waters Corporation). The gradient mobile phase: (A) $0.1 \%$ formic acid in water and (B) $0.1 \%$ formic acid in acetonitrile; 0 to $0.2 \mathrm{~min}, 10 \% \mathrm{~B} ; 0.2$ to $3 \mathrm{~min}, 10$ to $50 \% \mathrm{~B} ; 3$ to $8 \mathrm{~min}, 50$ to $99 \% \mathrm{~B} ; 8$ to 
$8.1 \mathrm{~min}, 99$ to $10 \% \mathrm{~B} ; 8.1$ to $10 \mathrm{~min}, 10 \% \mathrm{~B}$. The flow rate was set to $0.4 \mathrm{~mL} / \mathrm{min}$. High-resolution MS was performed on a Waters Q-TOF (Xevo G2-S, Waters Corp., Manchester, UK) equipped with an electrospray ion source in the positive and negative ion mode. In positive ion mode, the capillary voltage was $3.0 \mathrm{kV}$; the sampling cone voltage was $25 \mathrm{~V}$, and extraction cone voltage was $3.0 \mathrm{~V}$; desolvation gas flow was $600 \mathrm{~L} / \mathrm{h}$. In negative ion mode, the capillary voltage was $3.0 \mathrm{kV}$; the sampling cone voltage was $20 \mathrm{~V}$, and extraction cone voltage was $4.0 \mathrm{~V}$; desolvation gas flow was 700 $\mathrm{L} / \mathrm{h}$. Data of samples were collected in the centroid mode between $\mathrm{m} / \mathrm{z} 50$ and 1,500 , with a scan time of $0.2 \mathrm{~s}$ and interscan time of $0.1 \mathrm{~s}$. Data were acquired through Masslynx 4.1 (Waters Corporation, Milford, MA). Raw $\mathrm{MS}^{\mathrm{E}}$ data files were uploaded onto Progenesis QI software (Nonlinear Dynamics, 2018, version: 2.4; a Waters company, Newcastle upon Tyne, UK). Chromatographic alignment, data normalization, and peak picking were performed by Progenesis QI. All peaks were identified by the HMDB database (http:// www.hmdb.ca/) file in a local computer. The data were exported for the following analyses: $t$-test, and variable importance in projection plot analysis ( $\mathrm{Li}$ et al., 2017, 2018).

\section{Size-Dependent Characterization of Heat-Treated Lactoferrin}

The aggregation of heat-treated LF was monitored by determining particle size distribution. Referring to the methods in Leeb et al. (2015) with minor modification, the particle size of heat-treated LF was tested using Malvern Nano ZS (Malvern, UK), and the Z-average $\mathrm{d} \cdot \mathrm{nm}$ of protein size was calculated.

\section{Statistical Analysis}

All the data were expressed as mean \pm standard deviation. The data were analyzed using GraphPad Prism 6.0 software (GraphPad, San Diego, CA). All statistical analyses were conducted with Student's $t$-test. In the tests of cell viability and Western blotting, $P$-values $<0.05$ were considered to indicate statistically significant differences.

\section{RESULTS}

\section{Lactoferrin at a Concentration Above 500 mg/L Inhibited the Viability of PC-12 Cells}

To observe the effect of LF on PC-12 cell viability, the MTT assay was performed. The result showed no obvious difference in cell viability among the 0 to 100

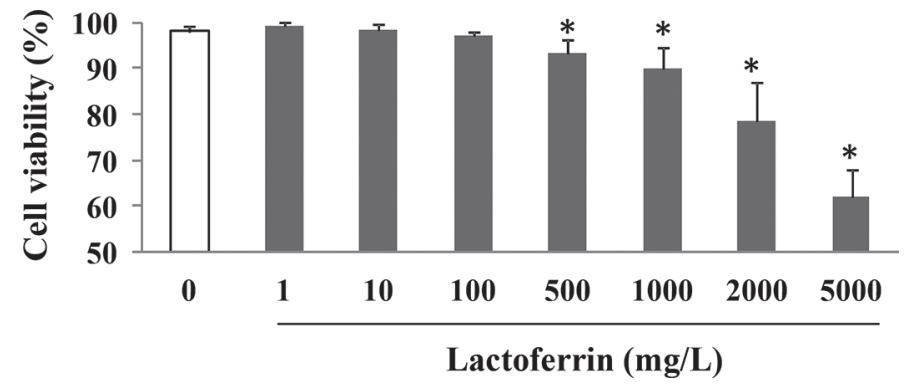

Figure 1. The effect of lactoferrin at different concentrations on the viability of rat pheochromocytoma 12 (PC-12) cells. ${ }^{*} P<0.05$, compared with the group without lactoferrin treatment, $\mathrm{n}=8$. Data are expressed as mean $\pm \mathrm{SD}$.

$\mathrm{mg} / \mathrm{L}$ groups, whereas cell viability at $500 \mathrm{mg} / \mathrm{L}$ or higher concentrations decreased significantly compared with the control $(P<0.05$; Figure 1$)$. In comparison with control, the cell viabilities of $1,000,2,000$, and $5,000 \mathrm{mg} / \mathrm{L}$ groups were $90.2 \pm 4.4,78.7 \pm 8.3$, and $62.1 \pm 5.8 \%$, respectively. Thus, $1,000 \mathrm{mg} / \mathrm{L}$ was selected as the proper concentration (cell viability $>90 \%$ ) for subsequent cellular experiments.

\section{Lactoferrin Modulated the TLR-4/MyD88/NF-KB/ TNF- $\alpha / I L-1 \beta$ Pathway in the Anoxia and Reoxygenation Cell Model}

To evaluate the expression of TLR-4/MyD88/NF$\kappa \mathrm{B} / \mathrm{TNF}-\alpha / \mathrm{IL}-1 \beta$ proteins in the anoxia and reoxygenation cell model and to investigate the effects of LF on modulating this pathway, these proteins were measured by Western blotting. The results demonstrated that the levels of these proteins had no apparent change with LF treatment alone, whereas in the OGD group, the levels of TLR-4, MyD88, NF- $\kappa$ B, TNF- $\alpha$, and IL-1 $\beta$ were significantly upregulated compared with the control $(P<0.05 ;$ Figure 2$)$. In the OGD + LF combination groups, LF without any heat treatment and LF with $50^{\circ} \mathrm{C}$ heating both inhibited the TLR-4-related inflammatory pathway, whereas LF solutions treated at 70 or $100^{\circ} \mathrm{C}$ were unable to inhibit this induction in the anoxia and reoxygenation cell model (Figure 2).

\section{Lactoferrin Modulated the TLR-4/MyD88/NF-KB/ TNF- $\alpha /$ IL-1 $\beta$ Pathway in the Cerebral Ischemic Reperfusion Mouse Model}

To further validate the effect of LF on modulating TLR-4-related pathway and to evaluate the role of heat treatment on this influence in a cerebral ischemic reperfusion mouse model, TLR-4/MyD88/NF- $\kappa \mathrm{B} / \mathrm{TNF}-\alpha /$ IL-1 $\beta$ proteins in brain tissue were measured by Western blotting. The results showed that the levels of TLR- 


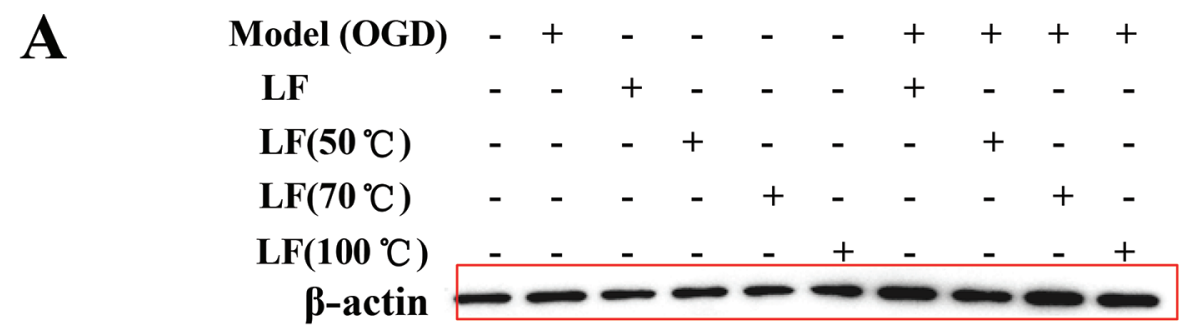

TLR-4 - -

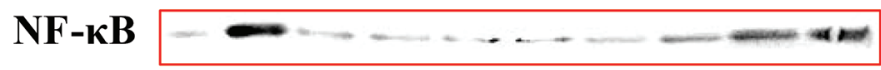

MyD88
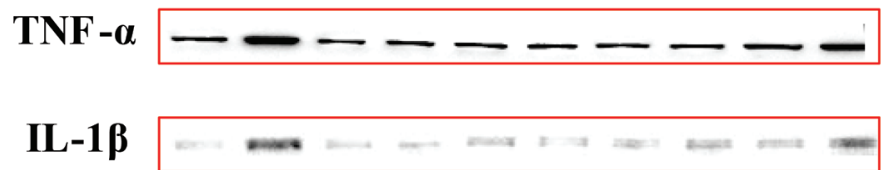

B
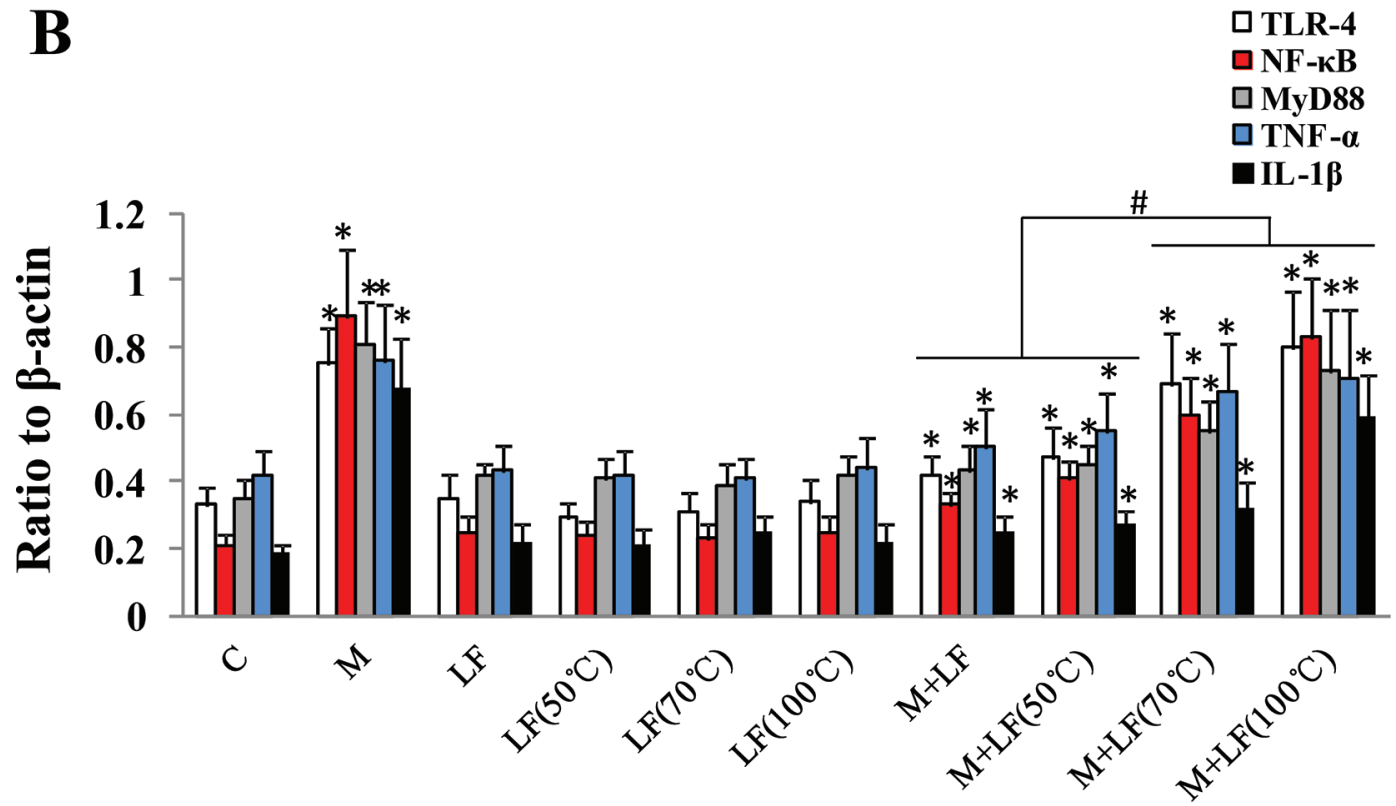

Figure 2. Protein expression of toll-like receptor 4 (TLR-4)-related pathway members in rat pheochromocytoma 12 (PC-12) cells in anoxia and reoxygenation cell models. (A) Western blotting bands of $\beta$-actin, TLR-4, myeloid differentiation protein 88 (MyD88), nuclear factor- $\kappa \mathrm{B}$

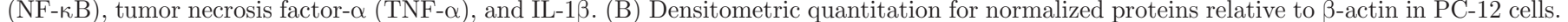
$\mathrm{C}=$ control; $\mathrm{M}=$ anoxia and reoxygenation cell model; $\mathrm{LF}=$ lactoferrin; OGD = oxygen and glucose deprivation. The final concentration of lactoferrin in the medium was $1 \mathrm{mg} / \mathrm{mL}$. All values were calculated from 3 independent experiments. ${ }^{*} P<0.05$ compared with the control; \#P $<0.05$ compared with the $\mathrm{M}+\mathrm{LF}$ group or $\mathrm{M}+\mathrm{LF}\left(50^{\circ} \mathrm{C}\right)$ group, $\mathrm{n}=3$. Data are expressed as mean $\pm \mathrm{SD}$.

4, MyD88, NF- $\kappa B$, TNF- $\alpha$, and IL-1 $\beta$ were also upregulated in model, and no obvious differences in these protein levels were observed among the control and LF, LF $70^{\circ} \mathrm{C}$, and LF $100^{\circ} \mathrm{C}$ groups $(P>0.05)$. Compared with the protein levels in the cerebral ischemic reperfu- sion mouse model, LF and heated lactoferrin (HLF) could inhibit the induction of these proteins to different degrees in a temperature-dependent manner; in particular, LF with $100^{\circ} \mathrm{C}$ heating nearly lost its ability to inhibit the TLR-4-related pathway (Figure 3). 

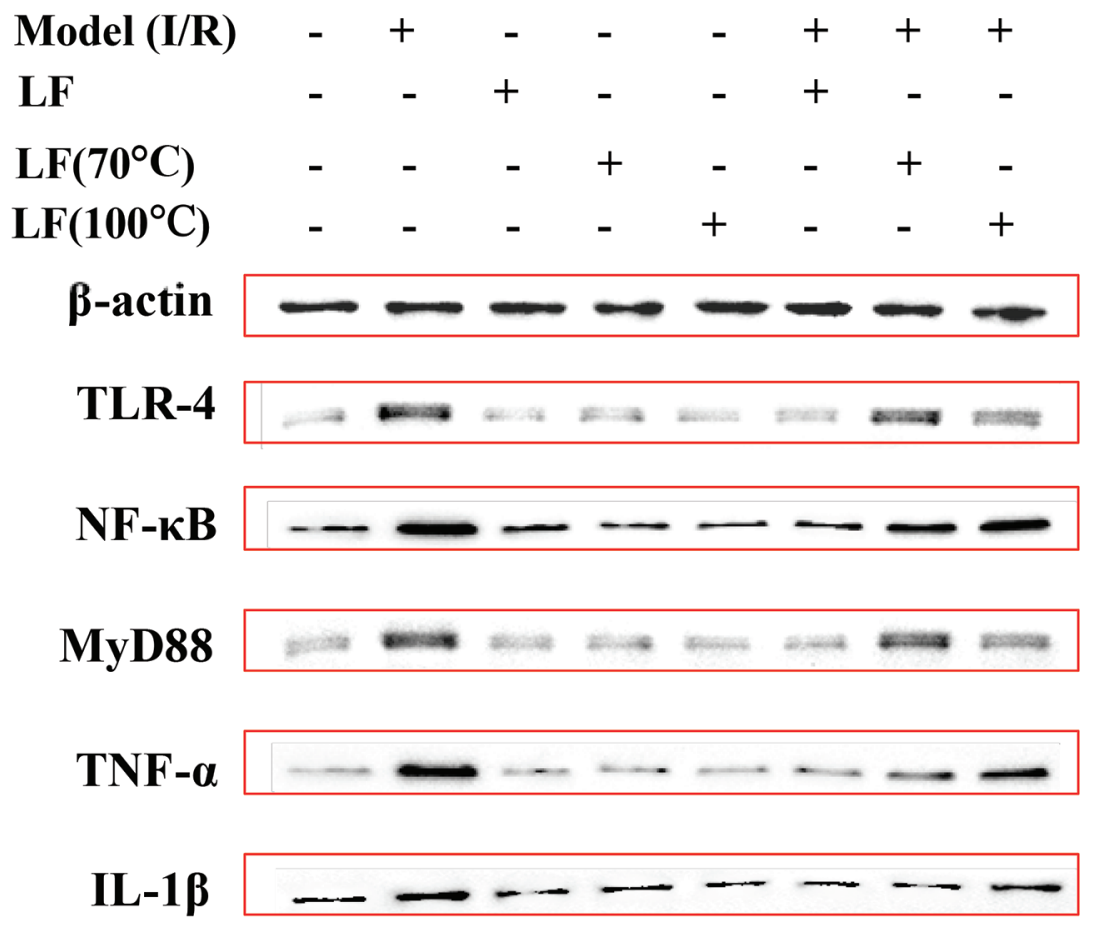

B

口TLR-4

口NF-кB

口MyD88

口TNF- $\alpha$

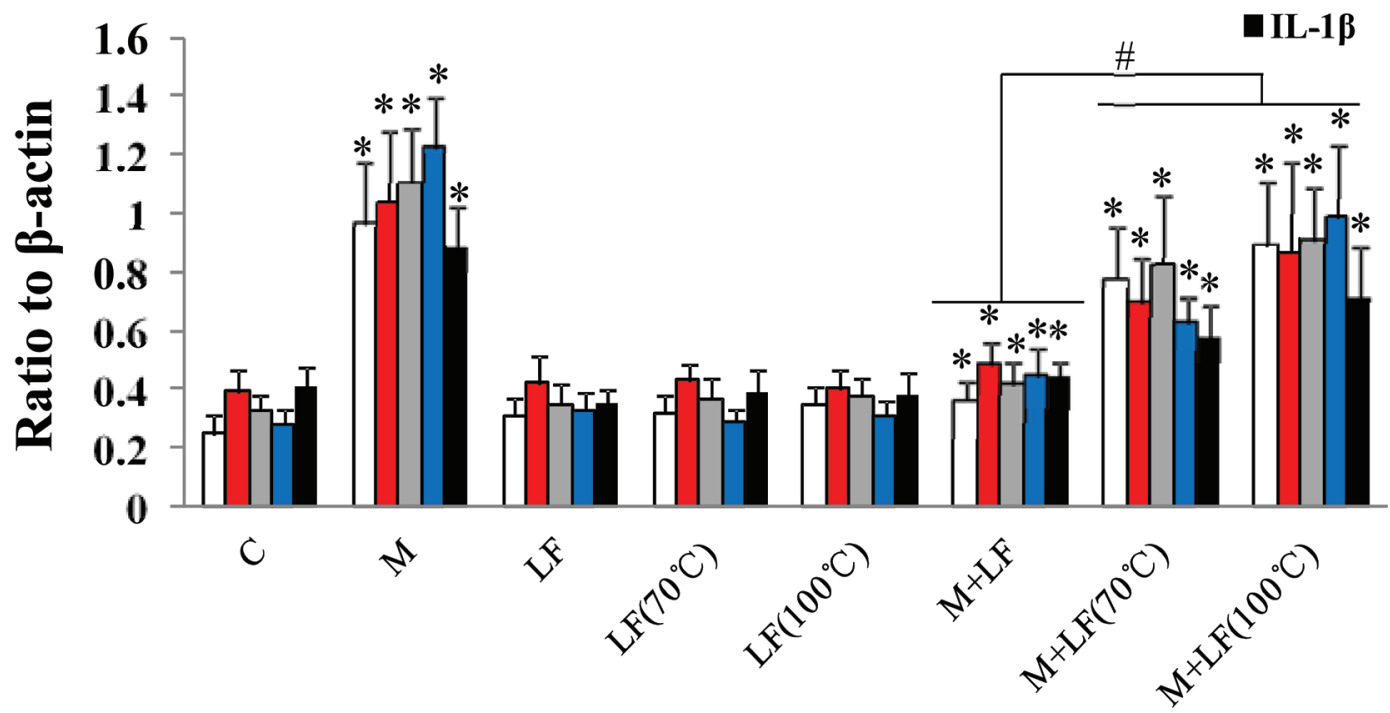

Figure 3. Protein expression of toll-like receptor 4 (TLR-4)-related pathway members in mouse brain tissue subjected to ischemic reperfusion (I/R). (A) Western blotting bands of $\beta$-actin, TLR-4, myeloid differentiation protein 88 (MyD88), nuclear factor- $\kappa \mathrm{B}$ (NF- $\mathrm{B}$ ), tumor necrosis factor- $\alpha$ (TNF- $\alpha$ ), and IL-1 $\beta$. (B) Densitometric quantitation of normalized proteins relative to $\beta$-actin in brain tissue. $C=$ control. $M=I / R$ mouse model. $\mathrm{LF}=$ lactoferrin. Data are expressed as the mean $\pm \mathrm{SD} .{ }^{*} P<0.05$ compared with the control; $\# P<0.05$ compared with the $\mathrm{M}$ $+\mathrm{LF}$ group, $\mathrm{n}=5$. Data are expressed as mean $\pm \mathrm{SD}$. 


\section{Level of Metabolites Affected by OGD With or Without Lactoferrin Treatment}

After HMDB identification, 360 metaboltes involved in 81 categories were identified in PC-12 cell lysate. The data set of the 360 metabolites were uploaded in a public repository: figshare (10.6084/m9.figshare.6025748). Forty-one metabolites were significantly changed (Table 1; Figure 4). Only 10 [glutathione, arachidonate, uridine, gentamicin, L-histidinol, pantothenic acid, lysophosphatidylcholine (LysoPC; 15:0), LysoPC (18:1), 7a,12a-dihydroxy-5b-cholestan-3-one, (S)homostachydrine] out of the 41 metabolites have their corresponding Kyoto Encyclopedia of Genes and Genomes ID numbers (C00051, C00219, C00299, C00505, C00860, C00864, C04230, C04230, C05453, C08283), and most of the metabolites are not well illustrated until now. Among them, glutathione was selected as a metabolite of interest, because its level in the OGD group decreased significantly in comparison with the control $(P<0.05)$. In the OGD + LF combination group, the glutathione concentration was higher than in the OGD group $(P<0.05)$, and no significant difference was observed in glutathione level between the OGD and OGD + HLF combination group. To further validate the role of glutathione in the protection

Table 1. Fold changes of 41 metabolites of rat pheochromocytoma 12 cells in an anoxia and reoxygenation cell model

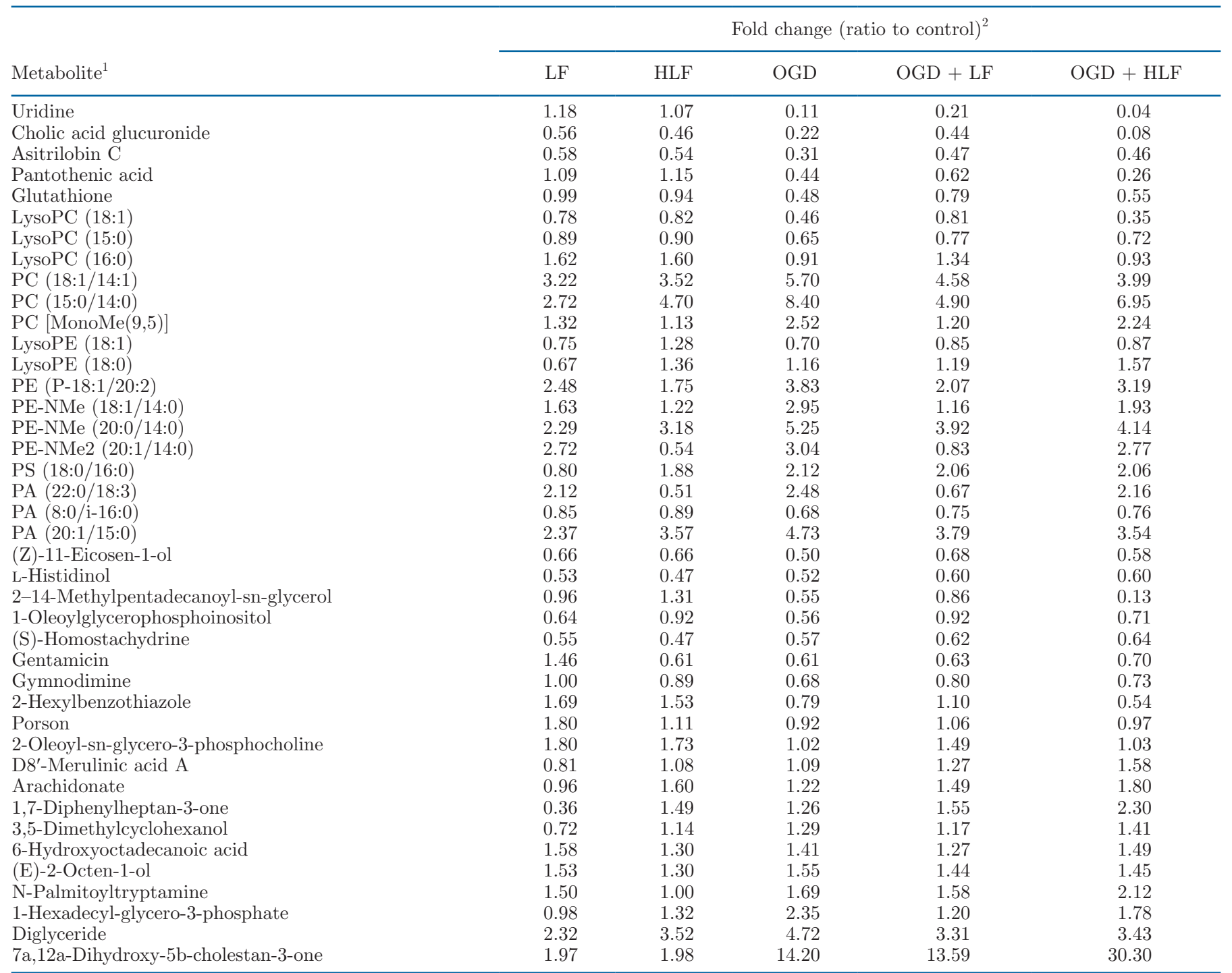

${ }^{1}$ LysoPC = lysophosphatidylcholine; PC = phosphatidylcholine; lysoPE = lysophosphatidylethanolamine; PE = phosphatidylethanolamine; PS $=$ phosphatidylserine; $\mathrm{PA}=$ phosphatidic acid; $\mathrm{NMe}=\mathrm{N}$-monomethyl; MonoMe = monomethyl; $\mathrm{i}=$ iso.

${ }^{2} \mathrm{LF}=$ lactoferrin; $\mathrm{HLF}=100^{\circ} \mathrm{C}$ heated lactoferrin; OGD $=$ oxygen and glucose deprivation. Fold change (ratio to control) $=$ metabolite concentration after treatment/metabolite concentration before treatment. 


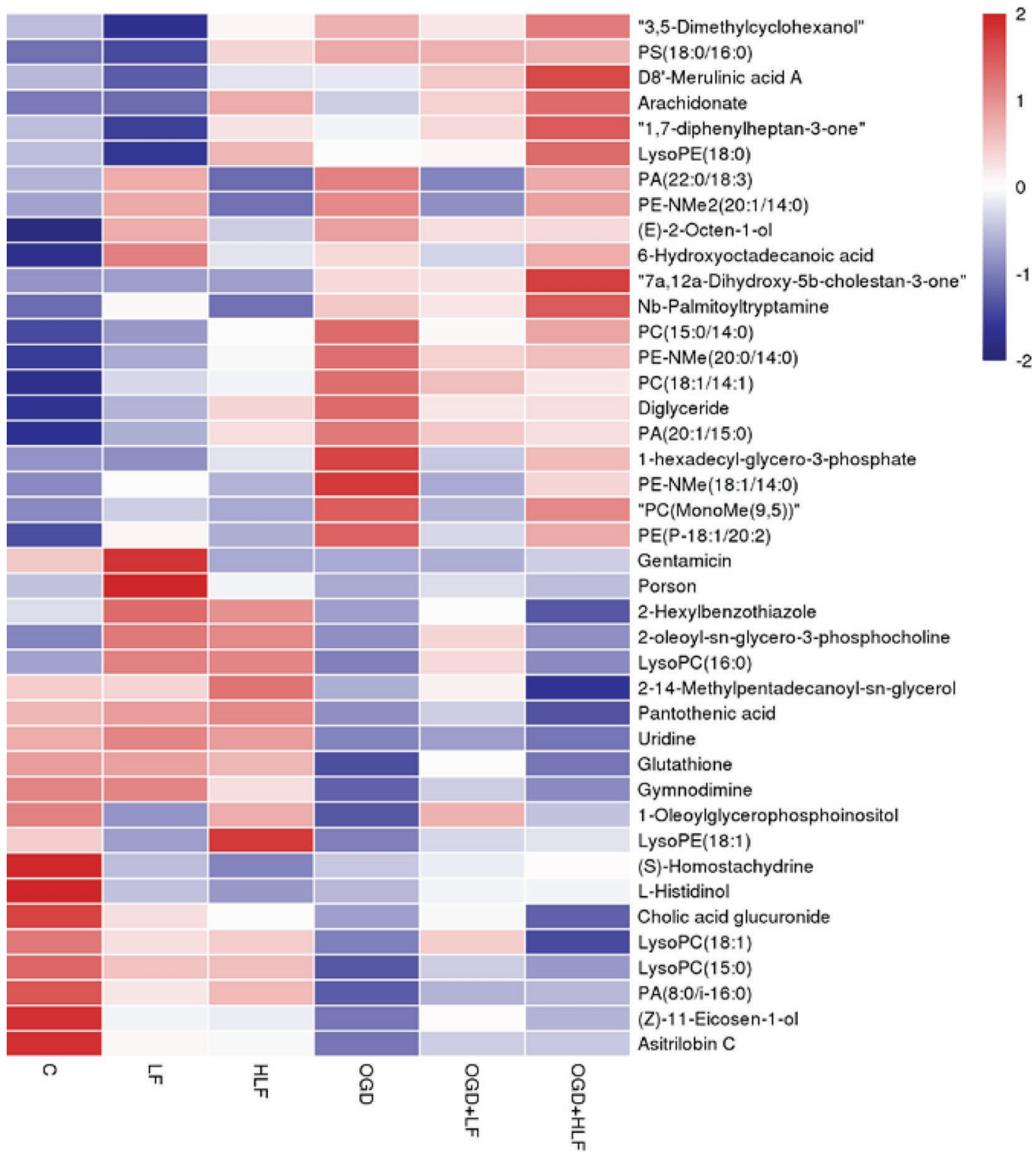

Figure 4. Heatmap of 41 significantly changed metabolites in rat pheochromocytoma 12 (PC-12) cells subjected to oxygen and glucose deprivation (OGD) and OGD + LF. Each row represents an individual metabolite, and each column represents an individual group. $\mathrm{C}=$ control; $\mathrm{M}=$ anoxia and reoxygenation cell model; $\mathrm{LF}=$ lactoferrin; $\mathrm{HLF}=100^{\circ} \mathrm{C}$ heated lactoferrin. The gradient color bar from red to blue represents from high to low concentrations of 41 metabolites in PC-12 cells in 6 groups. lysoPC = lysophosphatidylcholine; $\mathrm{PC}=$ phosphatidylcholine; lysoPE $=$ lysophosphatidylethanolamine; $\mathrm{PE}=$ phosphatidylethanolamine; $\mathrm{PS}=$ phosphatidylserine; $\mathrm{PA}=$ phosphatidic acid; NMe = N-monomethyl; MonoMe = monomethyl.

against ischemia, the expression levels of TLR-4 and other proteins were measured by Western blotting after glutathione supplement into the culture medium. The results showed that the addition of glutathione reduced the levels of TLR-4, MyD88, NF- $\kappa \mathrm{B}$, TNF- $\alpha$, and IL$1 \beta$ when compared with the OGD group $(P<0.05$, Figure 5A, 5B), and even the OGD + glutathione combination group showed no obvious difference in these proteins compared with the control, indicating that
LF modulated the TLR-4-related pathway, possibly by increasing the expression of glutathione.

\section{Heat Treatment Promoted the Formation of Protein Aggregates}

Heat treatment led LF to form insoluble aggregates (the color of LF solution turned from red to white), and except for the precipitate after centrifugation, the 
A
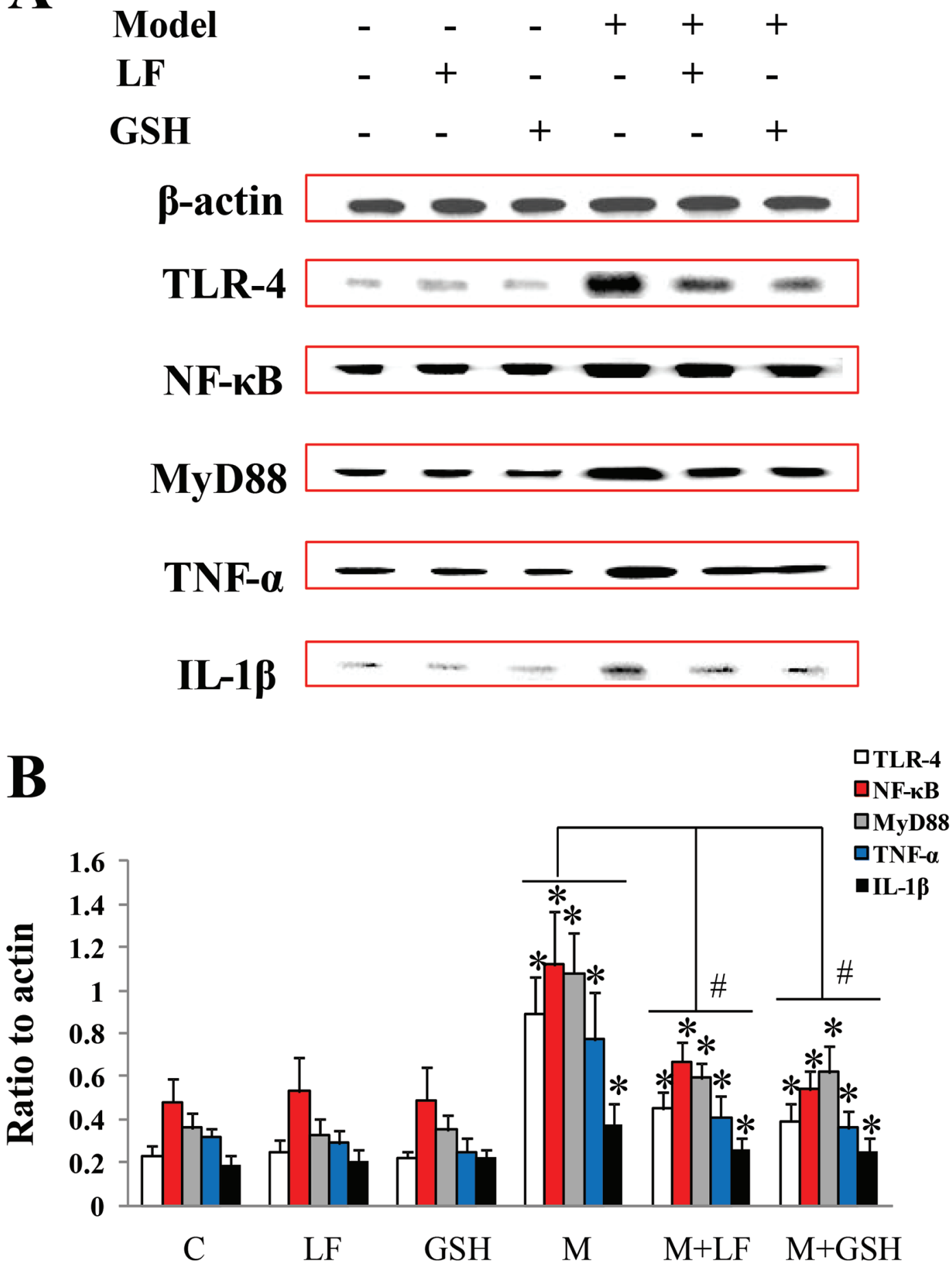

Figure 5. Glutathione modulated the toll-like receptor 4 (TLR-4)-related pathway in rat pheochromocytoma 12 (PC-12) cells in the anoxia and reoxygenation cell model. (A) Western blotting bands of $\beta$-actin, toll-like receptor 4 (TLR-4), myeloid differentiation protein 88 (MyD88), nuclear factor- $\kappa \mathrm{B}(\mathrm{NF}-\kappa \mathrm{B})$, tumor necrosis factor- $\alpha(\mathrm{TNF}-\alpha)$, and IL-1 $\beta$. (B) Densitometric quantitation of normalized protein levels relative to $\beta$-actin in PC-12 cells. $\mathrm{C}=$ control; $\mathrm{M}=$ anoxia and reoxygenation cell model; $\mathrm{LF}=$ lactoferrin; GSH $=$ glutathione; OGD $=$ oxygen and glucose deprivation. Data are expressed as the mean $\pm \mathrm{SD} .{ }^{*} P<0.05$ compared with the control; \# $P<0.05$ compared with the OGD (M) group, $\mathrm{n}=3$. Data are expressed as mean $\pm \mathrm{SD}$. 
particle size of $\mathrm{LF}$ (after $100^{\circ} \mathrm{C}$ heating) that still dissolved in supernatant was evaluated. The results demonstrated that the average size of denatured LF was $643.40 \pm 51.29 \mathrm{~nm}$, significantly larger compared with its original size $(22.85 \pm 3.43 \mathrm{~nm}$; Figure 6$)$, indicating that heat treatment promoted the formation of protein aggregates.

\section{DISCUSSION}

Cerebral ischemic reperfusion carries high morbidity and mortality (Cao et al., 2007; Liu et al., 2017; Lu and Wang, 2017). Because cerebral ischemic reperfusion is always accompanied by inflammatory reaction and oxidative stress, several anti-inflammatory and anti-oxidative drugs have been applied in the clinical treatment (Li et al., 2012; Liu et al., 2017). Several studies have demonstrated the protective effect of LF on ischemic injury (Zhang et al., 2012; van de Looij et al., 2014). Thus, LF is a promising protein for the intervention of damage caused by cerebral ischemia.

Regarding the metabolic course of LF in vivo, it has been confirmed that 60 to $80 \%$ of orally administered bovine LF remained intact after gastric digestion (Troost et al., 2001), and both human LF and bovine LF were shown to be relatively resistant to digestion by nearly all proteolytic enzymes (Brines and Brock, 1983). Human LF was even detected in its intact form in substantial amounts in the stool of exclusively breast-fed infants (Davidson and Lonnerdal, 1987),

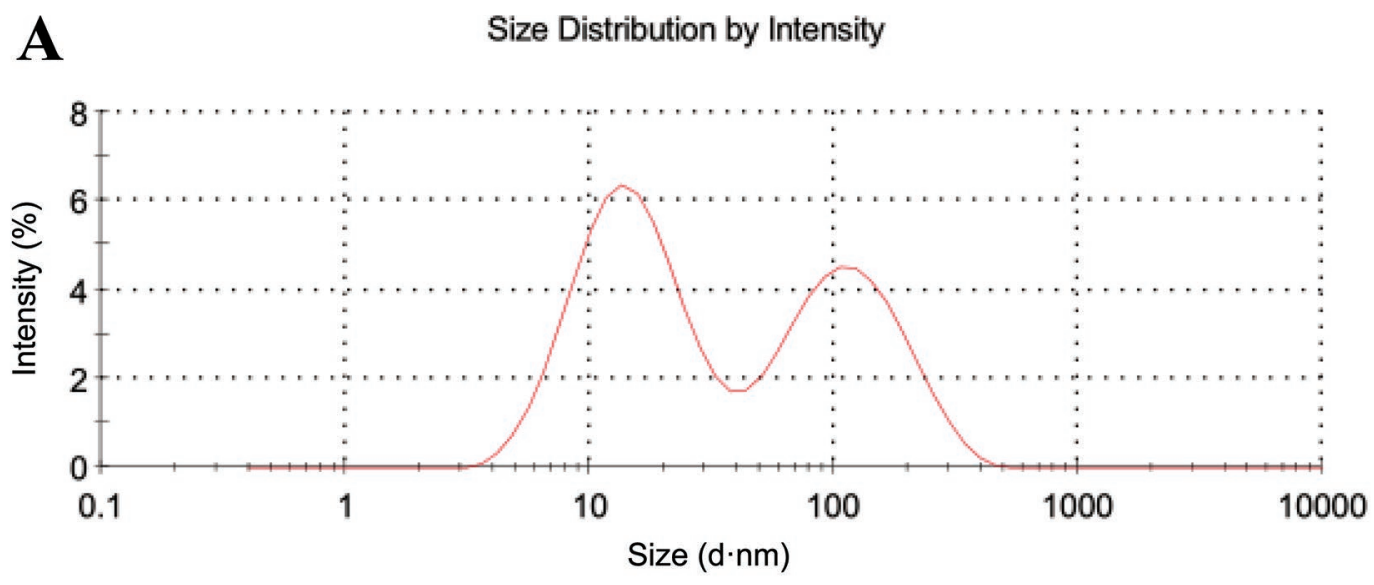

Record 481: 0
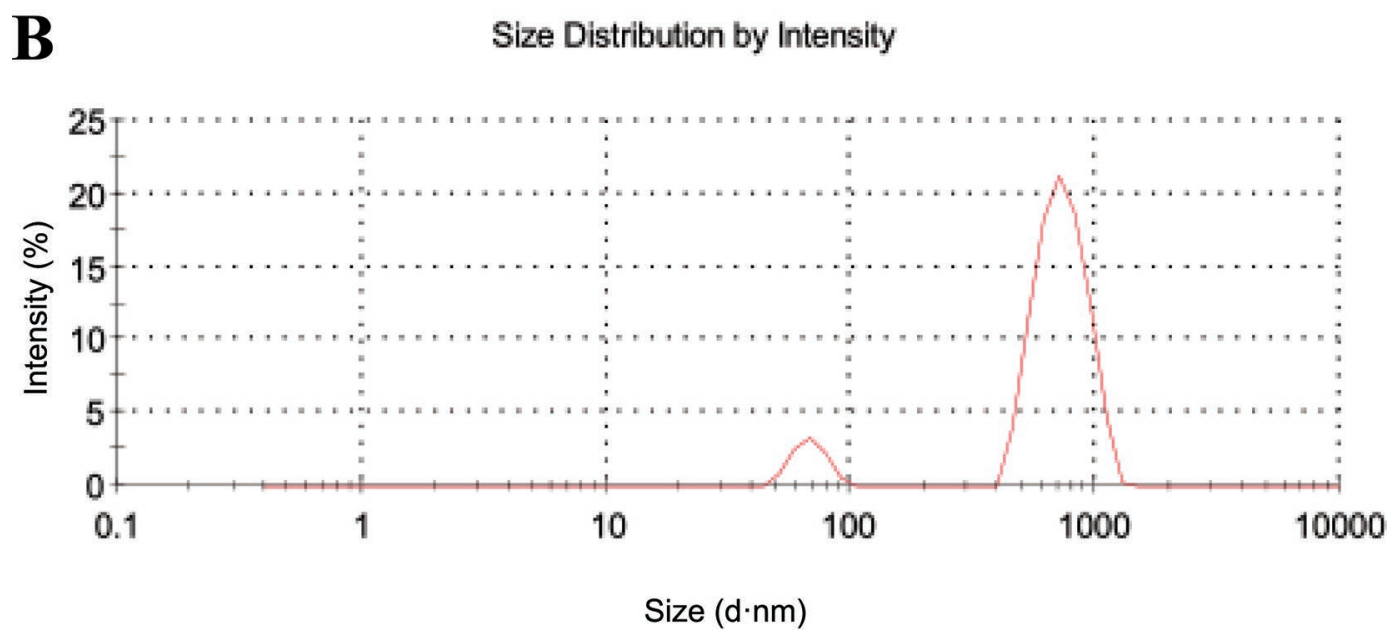

Record 484: 1

Figure 6. Size-dependent characterization of lactoferrin and heat-treated lactoferrin. (A) Particle size detection of lactoferrin without any heat treatment. (B) Particle size detection of lactoferrin heated at $100^{\circ} \mathrm{C}$. 
which demonstrated that LF could directly reach the colon (Mayeur et al., 2016).

In the present research, an in vitro anoxia and reoxygenation cell model and in vivo cerebral ischemic reperfusion mouse model were both used, and the effects of LF on the TLR-4/NF- $\kappa \mathrm{B} / \mathrm{TNF}-\alpha / \mathrm{IL}-1 \beta$ pathway members were detected. The data showed that LF inhibited the protein expression of TLR-4 and downstream inflammatory proteins, which were induced by oxygen and glucose deprivation and cerebral ischemic reperfusion. From the metabonomic analysis, it could be seen that LF altered numerous metabolites in PC12 cells under anoxia and reoxygenation. Glutathione was considered as a metabolite of interest in this study because it was one of the most changed metabolites in PC-12 cells affected by OGD and LF treatment, and its concentration was decreased in OGD group and recovered after LF treatment. Furthermore, glutathione is a strong anti-oxidative and anti-inflammatory tripeptide, and plays a key role in response to oxidative stress (Rahman, 2005; Homma and Fujii, 2015). Considering that cerebral ischemic reperfusion is closely related to oxidative stress and inflammatory reaction (Nagahiro et al., 1998; Nilupul Perera et al., 2006; Li et al., 2012), and that LF was reported to effectively alleviate oxidative and inflammatory damage (Chung et al., 2012; Okubo et al., 2016; Donovan, 2016), the level of glutathione, in response to LF intervention, may reflect the overall anti-oxidative capacity following cerebral ischemic reperfusion.

Lactoferrin, as a heat-sensitive protein, tends to be denatured upon ultra-high temperature treatment (Abe et al., 1991; Li et al., 2019). Therefore, bioactivities of HLF required further assessment. Thus, the effect of HLF on modulating TLR-4-related pathway was evaluated in the current study. The results demonstrated that LF inhibited the TLR-4-related pathway in vitro and in vivo in a temperature-dependent manner, and its effects decreased by more than $90 \%$ when heated at $100^{\circ} \mathrm{C}$. These data are in accordance with the loss of its anti-inflammatory, anti-bacterial, and anti-tumor capacities with heat treatment (Conesa et al., 2009, 2010; Chang et al., 2013; Liu et al., 2013; Li et al., 2019).

The loss of LF activity with heat treatment may be attributed to the change in its secondary structure, such as the transformation of $\alpha$-helixes to $\beta$-sheets, and in tertiary structure, such as aggregation (Brisson et al., 2007), which were in agreement with our particle size measurement of HLF. The molecular structure of LF could be related to its activity, and the special binding or regulatory sites might be hidden or blocked after aggregation. Leeb et al. (2015) found that denaturation and subsequent polymerization of another whey pro- tein, $\beta-\mathrm{LG}$, could not alter the degree of trypsinolysis, whereas the release of its functional peptides was significantly decreased. However, the influence of protein aggregation on the enzymatic digestibility and release of functional peptides of LF has not been well studied yet.

In conclusion, LF was found to be able to suppress the TLR-4-related pathway in anoxia and reoxygenation cell and cerebral ischemic reperfusion mouse models. After LF intervention, glutathione was significantly upregulated in OGD PC-12 cells. However, heat treatment decreased this activity of LF in a temperaturedependent manner. The temperature control in food processing of dairy products, especially milk proteins, needs more attention.

\section{ACKNOWLEDGMENTS}

We are grateful for support from two Key Labs, Key Laboratory of Quality \& Safety Control for Milk and Dairy Products, Laboratory of Quality and Safety Risk Assessment for Dairy Products, Ministry of Agriculture and Rural Affairs, Institute of Animal Sciences, Chinese Academy of Agricultural Sciences, China. We appreciate financial support from the Special Fund for Agroscientific Research in the public Interest (201403071), the Ministry of Modern Agro-Industry Technology Research System of China (CARS-36), and the Agricultural Science and Technology Innovation Program (ASTIP-IAS12). We especially appreciate the technological support from the core facility and Qingshi Meng at the Institute of Animal Sciences, Chinese Academy of Agricultural Sciences (CAAS; Beijing).

\section{REFERENCES}

Abe, H., H. Saito, H. Miyakawa, Y. Tamura, S. Shimamura, E. Nagao, and M. Tomita. 1991. Heat stability of bovine lactoferrin at acidic pH. J. Dairy Sci. 74:65-71. https://doi.org/10.3168/jds.S0022 -0302(91)78144-7.

Akira, S., and K. Takeda. 2004. Toll-like receptor signalling. Nat. Rev. Immunol. 4:499-511. https://doi.org/10.1038/nri1391.

Ando, K., K. Hasegawa, K. Shindo, T. Furusawa, T. Fujino, K. Kikugawa, H. Nakano, O. Takeuchi, S. Akira, T. Akiyama, J. Gohda, J. Inoue, and M. Hayakawa. 2010. Human lactoferrin activates NFkappaB through the Toll-like receptor 4 pathway while it interferes with the lipopolysaccharide-stimulated TLR4 signaling. FEBS J 277:2051-2066. https://doi.org/10.1111/j.1742-4658.2010.07620.x.

Andreev, D. E., P. B. O'Connor, A. V. Zhdanov, R. I. Dmitriev, I. N. Shatsky, D. B. Papkovsky, and P. V. Baranov. 2015. Oxygen and glucose deprivation induces widespread alterations in mRNA translation within 20 minutes. Genome Biol. 16:90. https://doi .org/10.1186/s13059-015-0651-z.

Brines, R. D., and J. H. Brock. 1983. The effect of trypsin and chymotrypsin on the in vitro antimicrobial and iron-binding properties of lactoferrin in human milk and bovine colostrum. Unusual resistance of human apolactoferrin to proteolytic digestion. Biochim. Biophys. Acta 759:229-235. https://doi.org/10.1016/0304 -4165(83)90317-3. 
Brisson, G., M. Britten, and Y. Pouliot. 2007. Heat-induced aggregation of bovine lactoferrin at neutral $\mathrm{pH}$ : Effect of iron saturation. Int. Dairy J. 17:617-624. https://doi.org/10.1016/j.idairyj.2006.09 .002 .

Cao, C. X., Q. W. Yang, F. L. Lv, J. Cui, H. B. Fu, and J. Z. Wang. 2007. Reduced cerebral ischemia-reperfusion injury in Toll-like receptor 4 deficient mice. Biochem. Biophys. Res. Commun. 353:509-514. https://doi.org/10.1016/j.bbrc.2006.12.057.

Chang, J. C., C. H. Chen, L. J. Fang, C. R. Tsai, Y. C. Chang, and T. M. Wang. 2013. Influence of prolonged storage process, pasteurization, and heat treatment on biologically-active human milk proteins. Pediatr. Neonatol. 54:360-366. https://doi.org/10.1016/ j.pedneo.2013.03.018.

Chung, S. H., H. B. Kang, J. W. Kim, S. S. Yoon, and M. S. Nam. 2012. The biological effects of bovine lactoferrin on inflammatory cytokine expression in the PMA stimulated cells. Korean J. Food. Sci. Anim. Resour. 32:364-368.

Conesa, C., C. Rota, E. Castillo, M. D. Perez, M. Calvo, and L. Sanchez. 2009. Antibacterial activity of recombinant human lactoferrin from rice: Effect of heat treatment. Biosci. Biotechnol. Biochem. 73:1301-1307. https://doi.org/10.1271/bbb.80814.

Conesa, C., C. Rota, E. Castillo, M. D. Pérez, M. Calvo, and L. Sánchez. 2010. Effect of heat treatment on the antibacterial activity of bovine lactoferrin against three foodborne pathogens. Int. J. Dairy Technol. 63:209-215. https://doi.org/10.1111/j.1471-0307 .2010.00567.x.

Davidson, L. A., and B. Lonnerdal. 1987. Persistence of human milk proteins in the breast-fed infant. Acta Paediatr. Scand. 76:733740. https://doi.org/10.1111/j.1651-2227.1987.tb10557.x.

Dehghan, M., A. Mente, S. Rangarajan, P. Sheridan, V. Mohan, R. Iqbal, R. Gupta, S. Lear, E. Wentzel-Viljoen, A. Avezum, P. Lopez-Jaramillo, P. Mony, R. P. Varma, R. Kumar, J. Chifamba, K. F. Alhabib, N. Mohammadifard, A. Oguz, F. Lanas, D. Rozanska, K. B. Bostrom, K. Yusoff, L. P. Tsolkile, A. Dans, A. Yusufali, A. Orlandini, P. Poirier, R. Khatib, B. Hu, L. Wei, L. Yin, A Deeraili, K. Yeates, R. Yusuf, N. Ismail, D. Mozaffarian, K. Teo, S. S. Anand, and S. Yusuf. 2018. Association of dairy intake with cardiovascular disease and mortality in 21 countries from five continents (PURE): a prospective cohort study. Lancet 392:2288-2297. https: //doi.org/10.1016/S0140-6736(18)31812-9.

Dial, E. J., A. J. Dohrman, J. J. Romero, and L. M. Lichtenberger. 2005. Recombinant human lactoferrin prevents NSAID-induced intestinal bleeding in rodents. J. Pharm. Pharmacol. 57:93-99. https://doi.org/10.1211/0022357055191.

Donovan, S. M. 2016. The role of lactoferrin in gastrointestinal and immune development and function: A preclinical perspective. J. Pediatr. 173(Suppl):S16-S28. https://doi.org/10.1016/j.jpeds 2016.02.072

Hayashida, K., T. Kaneko, T. Takeuchi, H. Shimizu, K. Ando, and E. Harada. 2004. Oral administration of lactoferrin inhibits inflammation and nociception in rat adjuvant-induced arthritis. J. Vet. Med. Sci. 66:149-154. https://doi.org/10.1292/jvms.66.149.

Homma, T., and J. Fujii. 2015. Application of glutathione as antioxidative and anti-aging drugs. Curr. Drug Metab. 16:560-571. https://doi.org/10.2174/1389200216666151015114515.

Ikeda, Y., S. Tajima, Y. Izawa-Ishizawa, Y. Kihira, K. Ishizawa, S. Yoshida, K. Aihara, K. Tsuchiya, and T. Tamaki. 2013. Bovine milk-derived lactoferrin exerts proangiogenic effects in an SrcAkt-eNOS-dependent manner in response to ischemia. J. Cardiovasc. Pharmacol. 61:423-429. https://doi.org/10.1097/FJC $.0 \mathrm{~b} 013 \mathrm{e} 318287 \mathrm{~d} 526$.

Leeb, E., A. Gotz, T. Letzel, S. C. Cheison, and U. Kulozik. 2015. Influence of denaturation and aggregation of beta-lactoglobulin on its tryptic hydrolysis and the release of functional peptides. Food Chem. 187:545-554. https://doi.org/10.1016/j.foodchem.2015.04 .034 .

Legrand, D. 2016. Overview of lactoferrin as a natural immune modulator. J. Pediatr. 173(Suppl):S10-S15. https://doi.org/10.1016/j .jpeds.2016.02.071.

Li, H., L. Xing, M. Zhang, J. Wang, and N. Zheng. 2018. The toxic effects of aflatoxin B1 and aflatoxin M1 on kidney through regu- lating L-proline and downstream apoptosis. BioMed Res. Int. 2018:9074861. https://doi.org/10.1155/2018/9074861.

Li, H. Y., H. G. Yang, P. Li, Y. Z. Wang, G. X. Huang, L. Xing, J. Q. Wang, and N. Zheng. 2019. Effect of heat treatment on the antitumor activity of lactoferrin in human colon tumor (HT29) model. J. Agric. Food Chem. 67:140-147. https://doi.org/10.1021/ acs.jafc.8b05131.

Li, H. Y., Z. Y. Yuan, Y. G. Wang, H. J. Wan, J. Hu, Y. S. Chai, F. Lei, D. M. Xing, and L. J. Du. 2012. Role of baicalin in regulating Toll-like receptor $2 / 4$ after ischemic neuronal injury. Chin. Med. J. (Engl.) 125:1586-1593.

Li, Y., Y. Jin, S. Yang, W. Zhang, J. Zhang, W. Zhao, L. Chen, Y. Wen, Y. Zhang, K. Lu, Y. Zhang, J. Zhou, and S. Yang. 2017. Strategy for comparative untargeted metabolomics reveals honey markers of different floral and geographic origins using ultrahighperformance liquid chromatography-hybrid quadrupole-orbitrap mass spectrometry. J. Chromatogr. A 1499:78-89. https://doi.org/ 10.1016/j.chroma.2017.03.071.

Liu, M., D. U. Ming, Y. Y. Kong, W. L. Xu, W. Song, and L. W. Zhang. 2013. Influence of heat treatment on the osteoblast-promoting activity of bovine lactoferrin. Food Sci. 34:301-304.

Liu, X., X. Zhang, F. Wang, X. Liang, Z. Zeng, J. Zhao, H. Zheng, X. Jiang, and Y. Zhang. 2017. Improvement in cerebral ischemiareperfusion injury through the TLR4/NF-kappaB pathway after Kudiezi injection in rats. Life Sci. 191:132-140. https://doi.org/10 $.1016 /$ j.lfs.2017.10.035.

Liu, Y., H. Yin, M. Zhao, and Q. Lu. 2014. TLR2 and TLR4 in autoimmune diseases: A comprehensive review. Clin. Rev. Allergy Immunol. 47:136-147. https://doi.org/10.1007/s12016-013-8402-y.

Lu, H., and B. Wang. 2017. SIRT1 exerts neuroprotective effects by attenuating cerebral ischemia/reperfusion-induced injury via targeting p53/microRNA-22. Int. J. Mol. Med. 39:208-216. https:// doi.org/10.3892/ijmm.2016.2806.

Martin-de-Saavedra, M. D., L. del Barrio, N. Canas, J. Egea, S. Lorrio, E. Montell, J. Verges, A. G. Garcia, and M. G. Lopez. 2011 Chondroitin sulfate reduces cell death of rat hippocampal slices subjected to oxygen and glucose deprivation by inhibiting p38, NFkappaB and iNOS. Neurochem. Int. 58:676-683. https://doi .org/10.1016/j.neuint.2011.02.006.

Mayeur, S., S. Spahis, Y. Pouliot, and E. Levy. 2016. Lactoferrin, a pleiotropic protein in health and disease. Antioxid. Redox Signal. 24:813-836. https://doi.org/10.1089/ars.2015.6458.

Nagahiro, S., M. Uno, K. Sato, S. Goto, M. Morioka, and Y. Ushio. 1998. Pathophysiology and treatment of cerebral ischemia. J. Med. Invest. 45:57-70.

Napoli, I., and H. Neumann. 2009. Microglial clearance function in health and disease. Neuroscience 158:1030-1038. https://doi.org/ 10.1016/j.neuroscience.2008.06.046.

Nilupul Perera, M., H. K. Ma, S. Arakawa, D. W. Howells, R. Markus, C. C. Rowe, and G. A. Donnan. 2006. Inflammation following stroke. J. Clin. Neurosci. 13:1-8. https://doi.org/10.1016/j.jocn 2005.07.005.

NRC (National Research Council). 2011. Guide for the Care and Use of Laboratory Animals. 8th ed. National Academies Press, Washington, DC.

Okubo, K., M. Kamiya, Y. Urano, H. Nishi, J. M. Herter, T. Mayadas, D. Hirohama, K. Suzuki, H. Kawakami, M. Tanaka, M. Kurosawa S. Kagaya, K. Hishikawa, M. Nangaku, T. Fujita, M. Hayashi, and J. Hirahashi. 2016. Lactoferrin suppresses neutrophil extracellular traps release in inflammation. EBioMedicine 10:204-215. https:// doi.org/10.1016/j.ebiom.2016.07.012.

Puddu, P., D. Latorre, M. Carollo, A. Catizone, G. Ricci, P. Valenti, and S. Gessani. 2011. Bovine lactoferrin counteracts Toll-like receptor mediated activation signals in antigen presenting cells. PLoS One 6:e22504. https://doi.org/10.1371/journal.pone.0022504.

Rahman, I. 2005. Regulation of glutathione in inflammation and chronic lung diseases. Mutat. Res. 579:58-80. https://doi.org/10 .1016/j.mrfmmm.2005.02.025.

Redwan, E. M., N. A. El-Baky, A. M. Al-Hejin, M. N. Baeshen, H. A. Almehdar, A. Elsaway, A. B. Gomaa, S. B. Al-Masaudi, F. A. Al-Fassi, I. E. AbuZeid, and V. N. Uversky. 2016. Significant 
antibacterial activity and synergistic effects of camel lactoferrin with antibiotics against methicillin-resistant Staphylococcus aureus (MRSA). Res. Microbiol. 167:480-491. https://doi.org/10.1016/j resmic.2016.04.006.

Rüegg, M., U. Moor, and B. Blanc. 1977. A calorimetric study of the thermal denaturation of whey proteins in simulated milk ultrafiltrate. J. Dairy Res. 44:509-520. https://doi.org/10.1017/ S002202990002046X.

Sun, J., F. Z. Ren, L. Xiong, L. Zhao, and H. Y. Guo. 2016. Bovine lactoferrin suppresses high-fat diet induced obesity and modulates gut microbiota in C57BL/6J mice. J. Funct. Foods 22:189-200. https://doi.org/10.1016/j.jff.2016.01.022.

Tang, S. C., J. D. Lathia, P. K. Selvaraj, D. G. Jo, M. R. Mughal, A. Cheng, D. A. Siler, W. R. Markesbery, T. V. Arumugam, and M. P. Mattson. 2008. Toll-like receptor-4 mediates neuronal apoptosis induced by amyloid beta-peptide and the membrane lipid peroxidation product 4-hydroxynonenal. Exp. Neurol. 213:114-121. https://doi.org/10.1016/j.expneurol.2008.05.014.

Teeling, J. L., and V. H. Perry. 2009. Systemic infection and inflammation in acute CNS injury and chronic neurodegeneration: Underlying mechanisms. Neuroscience 158:1062-1073. https://doi.org/10 .1016/j.neuroscience.2008.07.031.

Togawa, J., H. Nagase, K. Tanaka, M. Inamori, A. Nakajima, N. Ueno, T. Saito, and H. Sekihara. 2002. Oral administration of lactoferrin reduces colitis in rats via modulation of the immune system and correction of cytokine imbalance. J. Gastroenterol. Hepatol. 17:1291-1298. https://doi.org/10.1046/j.1440-1746.2002.02868.x.

Troost, F. J., J. Steijns, W. H. Saris, and R. J. Brummer. 2001. Gastric digestion of bovine lactoferrin in vivo in adults. J. Nutr. 131:2101-2104. https://doi.org/10.1093/jn/131.8.2101.

van de Looij, Y., V. Ginet, A. Chatagner, A. Toulotte, E. Somm, P. S. Huppi, and S. V. Sizonenko. 2014. Lactoferrin during lacta- tion protects the immature hypoxic-ischemic rat brain. Ann. Clin. Transl. Neurol. 1:955-967. https://doi.org/10.1002/acn3.138.

Xu, W., R. P. Zha, W. Y. Wang, and Y. P. Wang. 2007. Effects of scutellarin on PKCgamma in PC12 cell injury induced by oxygen and glucose deprivation. Acta Pharmacol. Sin. 28:1573-1579. https:// doi.org/10.1111/j.1745-7254.2007.00502.x.

Yao, L., E. M. Kan, J. Lu, A. Hao, S. T. Dheen, C. Kaur, and E. A. Ling. 2013. Toll-like receptor 4 mediates microglial activation and production of inflammatory mediators in neonatal rat brain following hypoxia: Role of TLR4 in hypoxic microglia. J. Neuroinflammation 10:23. https://doi.org/10.1186/1742-2094-10-23.

Zhan, X., J. Gao, Y. Liu, J. Hu, Y. Xue, and B. Wu. 2014. Lactoferrin downregulates the expression of toll like receptor 4 stimulated by lipopolysaccharide in human periodontal ligament cells. West China Journal of Stomatology 32:166-170.

Zhang, T., Y. Wang, R. Ban, L. Tong, H. Qiao, H. Lao, H. Zhao, X. Jiang, X. Sun, and F. Zhang. 2012. Oral administration of lactoferrin attenuates intestinal ischemia-reperfusion injury in rats. Eur. Surg. Res. 49:99-106. https://doi.org/10.1159/000342633.

Zhu, J. R., Y. F. Tao, S. Lou, and Z. M. Wu. 2010. Protective effects of ginsenoside $\mathrm{Rb}(3)$ on oxygen and glucose deprivation-induced ischemic injury in PC12 cells. Acta Pharmacol. Sin. 31:273-280. https://doi.org/10.1038/aps.2010.9.

\section{ORCIDS}

Nan Zheng $\odot$ https://orcid.org/0000-0002-5365-9680

Jia-Qi Wang @ https://orcid.org/0000-0001-8841-0124 